\title{
PERSEPSI ETIS PELAKU AKUNTANSI TERHADAP PRAKTIK MANAJEMEN LABA BERDASARKAN PROFESI AKUNTANSI DAN JENDER 1
}

\section{Komala Inggarwati dan Arnold Kaudin}

Fakultas Ekonomika dan Bisnis Universitas Kristen Satya Wacana, email: anots@hotmail.com

\begin{abstract}
S
Managerial discretions in accounting and presures from stakeholders encourage earnings management. Such a practice creates ethical problems in business. The purpose of this study is to observe ethical perceptions in earnings management from acountants, both academics and profesional accountants, and ethical perceptions based on gender. Earnings management is classified into manipulation in accounting activity and in operational decision making.

This study covers 156 subjects consists of 65 professional accountants from three public accountant firms and five companies and 91 academics from two universities in Central Java. Seven questions/cases adopted from Merchant (1989) and Fischer dan Rosenzweig (1995) were introduced to subjects and subjects were asked to assess whether it was ethical or not on a scale of 5 where 1 indicates the most ethical and 5 indicates the most unethical.

The findings show that academics see manipulation in operational decision making as less ethical compared to practitioners while practitioners see manipulation in accounting as less ethical. Furthermore, practitioners see manipulation in operational decision as more ethical than manipulation in accounting while for academics there is no significant differences. Finally, there is not any significant difference on the ethical perception between female and male.
\end{abstract}

Keywords: ethical perception, earnings management, accounting manipulation, operational decision manipulation, gender

\footnotetext{
${ }^{1}$ Draft tulisan ini pernah dipresentasikan pada Seminar Nasional Ilmu Manajemen, Fakultas Ekonomi Universitas Islam Indonesia, Yogyakarta, 5 Februari 2010. Draft tersebut belum memasukan variabel jender dan ditulis ulang.
} 


\section{PENDAHULUAN}

Manajemen laba merupakan bentuk intervensi manajemen dalam penyusunan laporan keuangan. Intervensi yang dilakukan melalui manipulasi terhadap angka-angka akuntansi yang dilaporkan memunculkan berbagai skandal akuntansi, seperti pada kasus transaksi off-balance sheet Enron Energy tahun 2000, kasus peningkatan pendapatan Xerox tahun 1997-2000 dan sebagainya. Di Indonesia, hal ini pun pernah menjadi isu, seperti antara lain pada kasus mark up laba Kimia Farma tahun 2001 dan kasus pembukuan ganda Lippo Bank tahun 2002.

Pada kenyataannya terdapat pandangan yang berbeda-beda terhadap praktik manajemen laba dan hal ini menimbulkan dilema etis. Pada satu sisi, manajemen laba dipandang sebagai suatu tindakan yang seharusnya tidak boleh dilakukan karena dengan adanya manajemen laba infomasi yang diberikan tidak sepenuhnya mencerminkan keadaan perusahaan dan mengaburkan nilai perusahaan sesungguhnya. Tindakan tersebut dapat menyebabkan stakeholders keliru dalam mengambil keputusan. Pada sisi yang lain, manajemen laba dianggap sebagai sesuatu yang wajar dan merupakan tindakan rasional untuk memanfaatkan fleksibilitas dalam ketentuan untuk pelaporan keuangan.

Persepsi yang berbeda terhadap persoalan-persoalan etis dapat terjadi karena perbedaan profesi (Diantaranya Rahmawati dan Sulardi 2003, Elias 2002; Cole dan Smith 1996; Fischer dan Rosenzweig 1995), jenis kelamin (Diantaranya Rueger dan King 1992; Sikula dan Costa 1994; Tsalikis dan Ortiz-Buonafina 1990; Betz, O'Connell; Shepard 1989), karakteristik personal (Misalya Arlow 1991), keyakinan (Misalnya Pomeranz 2004), budaya (Misalnya Spain dkk. 2002) dan sebagainya.

Penelitian ini bertujuan untuk memperoleh gambaran mengenai persepsi etis para pelaku akuntansi terhadap persoalan-persoalan etis khususnya yang terkait dengan praktik manajemen laba. Pelaku akuntansi adalah pihak yang terlibat dalam penyusunan laporan keuangan. Memahami persepsi pelaku akuntansi terhadap manajemen laba diharapkan dapat memberi gambaran mengenai perilaku mereka dalam penyusunan laporan keuangan. Lebih lanjut, pelaku akuntansi dipilah menjadi akademisi dan praktisi akuntansi untuk melihat kesenjangan yang ada antara dunia akademis sebagai penghasil calon akuntan dan dunia praktis. Penelitian ini juga memilah persepsi etis pelaku akuntansi berdasar jender untuk melihat kemungkinan perbedaan persepsi antara perempuan dan laki-laki. 
Dengan demikian, pertanyaan penelitian yang hendak dijawab dalam penelitian ini adalah: apakah terdapat perbedaan persepsi etis terhadap manajemen laba (1) antara akademisi dan praktisi akuntansi dan (2) antara laki-laki dan perempuan. Persepsi para pelaku akuntansi tersebut ditinjau dari praktik manajemen laba yang dilakukan melalui manipulasi keputusan operasi dan manipulasi akuntansi.

Penelitian ini bermanfaat untuk mengetahui ada tidaknya kesenjangan pemahaman etika terhadap praktik manajemen laba antara akademisi dan praktisi akuntansi dan antara perempuan dan laki-laki. Temuan yang diperoleh diharapkan dapat dijadikan acuan bagi pengembangan pengajaran etika maupun akuntansi.

\section{TINJAUAN PUSTAKA DAN PENGEMBANGAN HIPOTESIS}

\section{Persepsi etis terhadap praktik manajemen laba berdasarkan profesi}

Persepsi etis pelaku akuntansi terhadap praktik manajemen laba dapat dipengaruhi oleh profesi akuntansi. Adanya perbedaan lingkungan kerja dan permasalahan yang dihadapi akuntan akademisi dan praktisi memungkinkan timbulnya perbedaan persepsi etis antara akuntan akademisi (termasuk akademisi yang minim melakukan praktik) dengan akuntan praktisi. Misalnya, Zoraifi (2005), terkait dengan situasi konflik audit, menemukan bahwa interaksi antara pengalaman kerja dengan persepsi etis adalah signifikan dan mempengaruhi auditor.

Pada umumnya penelitian yang menyangkut persepsi etis akuntan berdasar profesi dibedakan menjadi persepsi etis mahasiswa, akuntan pendidik, dan praktisi akuntan. Fischer dan Rosenzweig (1995) meneliti perbedaan persepsi etis terhadap manajemen laba antara mahasiswa S1, mahasiswa MBA dan praktisi akuntansi di AS. Mereka menemukan bahwa mahasiswa cenderung lebih lunak dalam menilai etika manipulasi laba dibanding praktisi akuntan. Mereka juga menemukan bahwa subyek penelitian memiliki toleransi yang lebih besar terhadap manipulasi keputusan operasi dibanding manipulasi akuntansi.

Elias (2002) dalam studinya yang meliputi 763 responden praktisi dan akademisi menemukan bahwa dalam manajemen laba praktisi akuntansi lebih dapat menerima manipulasi keputusan operasi daripada mahasiswa akuntansi. Selain itu, baik praktisi maupun mahasiswa memandang manipulasi akuntansi sebagai tindakan yang tidak etis namun terdapat kecenderungan bahwa mahasiswa lebih toleran. 
Perbedaan persepsi etis antara mahasiswa dengan praktisi juga terjadi dalam bidang bisnis. Cole dan Smith (1996) meneliti perbedaan persepsi terhadap etika bisnis antara mahasiswa dengan pelaku bisnis. Dalam studi tersebut subyek diminta untuk merespon suatu permasalahan sebagaimana 1) seorang pelaku bisnis merespon dan 2) merespon dengan pertimbangan etis. Dalam studi yang melibatkan 537 mahasiswa sekolah bisnis tingkat senior dan 158 pelaku bisnis ini ditemukan bahwa mahasiswa cenderung lebih menerima respon yang secara etis ambigu (membingungkan) dibanding pelaku bisnis. Selain itu pandangan mahasiswa terhadap etika para pelaku bisnis lebih negatif dibanding para pelaku bisnis memandang dirinya.

Studi mengenai perbedaan persepsi etis dalam manajemen laba juga dilakukan di Indonesia. Rahmawati dan Sulardi (2003) yang dalam studinya melibatkan akuntan pendidik, mahasiswa akuntansi, dan manajer di Surakarta justru menemukan bahwa secara umum tidak terdapat perbedaan yang signifikan antara persepsi etis terhadap praktik manajemen laba dari akuntan pendidik, mahasiswa akuntansi dan manajer. Sejalan dengan hal tersebut, Martadi dan Suranta (2006) tidak menemukan perbedaan persepsi terhadap etika bisnis antara akuntan laki-laki, mahasiswa akuntansi, dan karyawan bagian akuntansi dengan akuntan perempuan, mahasiswi akuntansi, dan karyawati di bagian akuntansi.

Pada studi lainnya, Rustiana (2006) menemukan adanya perbedaan persepsi etis antara mahasiswa akuntansi dengan auditor dalam situasi dilema etis akuntansi. Situasi dilema etis dalam studi tersebut adalah volume penjualan yang dimajukan lebih awal dengan motif mengejar bonus dan persetujuan kredit yang dilandaskan pada hubungan baik. Persepsi etis dalam studi tersebut diukur dengan multidimensional ethics scale yang diadopsi dari studi Reidenbach dan Robin.

Ludigdo dan Machfoedz (1999) menemukan perbedaan signifikan antara persepsi akuntan dan mahasiswa akuntansi terhadap etika bisnis. Menurut Ludigdo dan Machfoedz, akuntan memiliki persepsi yang lebih baik dibandingkan dengan mahasiswa. Penelitian mereka melibatkan 116 responden akuntan publik dan akuntan pendidik serta 159 mahasiswa akuntansi.

Tinjauan literatur yang dilakukan Ford dan Richardson (1994) atas berbagai penelitian tentang variabel-variabel yang mempengaruhi pengambilan keputusan etis menyimpulkan adanya hasil yang inkonklusif dan/atau tidak konsisten. Pada beberapa penelitian atribut-atribut personal (umur, jenis kelamin, kebangsaan, dan sebagainya) memiliki kaitan dengan keyakinan dan perilaku pengambilan keputusan etis namun tidak pada penelitian lainnya. 
Berdasarkan uraian di atas, hipotesis pertama dalam penelitian ini adalah terdapat perbedaan persepsi etis yang nyata terhadap praktik manajemen laba antara akademisi dan praktisi.

\section{Persepsi etis terhadap manipulasi keputusan operasional dan manipulasi akuntansi}

Merchant (1990) memilah tindakan manajemen laba sebagai operating decisions manipulation (Manipulasi keputusan operasi) dan accounting manipulation (Manipulasi akuntansi). Manipulasi keputusan operasi berkaitan dengan keputusan-keputusan operasi yang mempengaruhi arus kas dan laba perusahaan pada suatu periode tertentu, seperti menggeser pengeluaran yang sudah dianggarkan tahun ini ke tahun berikutnya agar laba tahun ini menjadi lebih besar sementara manipulasi akuntansi berkaitan dengan memanfaatkan fleksibilitas dalam pemilihan metode-metode akuntansi untuk mengubah angka laba seperti perubahan metode penyusutan dan perubahan besarnya cadangan.

Parfet (2001) mengklasifikasikan manipulasi keputusan operasi sebagai praktik yang wajar karena dilakukan untuk menstabilkan atau memperoleh hasil yang positif melalui perencanaan operasional sebagai bagian dari well-managed business sedangkan manipulasi akuntansi dianggap ilegal karena intervensi terhadap penyusunan laporan keuangan ditujukan untuk menyembunyikan kinerja operasional sesungguhnya dengan menciptakan catatan akuntansi artificial atau melonggarkan estimasi-estimasi melebihi batas-batas yang rasional.

Bruns dan Merchant (1990) dan Fischer dan Rosenzweig (1995) menemukan bahwa tindakan manipulasi keputusan operasional secara etika lebih dapat diterima dibanding dengan tindakan manipulasi akuntansi. Penelitian Fischer dan Rosenzweig merupakan replikasi dari penelitian Bruns dan Merchant dengan subyek yang berbeda. Subyek penelitian Bruns dan Merchant adalah manajer atau pengambil keputusan sementara subyek Fischer dan Rosenzweig adalah akuntan. Bahwa manipulasi keputusan operasional secara etika lebih dapat diterima oleh responden, Fischer dan Rosenzweig berpendapat hal tersebut disebabkan oleh cara pandang manusia pada umumnya terhadap etika dimana etika dipandang sebagai peraturan (rule). Maka pelanggaran terhadap peraturan akuntansi yang dinyatakan secara eksplisit dipandang lebih tidak etis dibanding manipulasi keputusan operasi dimana dalam penelitian mereka manipulasi tidak dinyatakan secara eksplisit sebagai peraturan. 
Hipotesis kedua pada penelitian ini adalah terdapat perbedaan yang nyata antara persepsi etis terhadap manajemen laba yang dilakukan melalui manipulasi keputusan operasional dengan yang dilakukan melalui manipulasi akuntansi.

\section{Persepsi etis terhadap praktik manajemen laba berdasarkan jender}

Perbedaan pandangan etis antara perempuan dan laki-laki dijelaskan oleh teori gender socialization dan occupational socialization (Mason dan Mudrack 1996). Teori gender socialization menjelaskan bagaimana seseorang mempelajari norma, kebiasaan, dan ideologi sejak masih kanak-kanak dalam rangka berpartisipasi dalam kehidupan bermasyarakat. Perempuan cenderung memandang dilema etis berdasarkan pengertian, tanggung jawab, dan perhatian pada orang lain sementara laki-laki cenderung memandangnya berdasarkan aturan-aturan, hak, fairness, dan justice (Peterson dkk. 2001). Hal inilah yang menyebabkan perempuan dan laki-laki dapat memiliki pandangan etis yang berbeda. Pada sisi lain, menurut teori occupational socialization, terdapat kemiripan etika, norma, dan perilaku yang terkait dengan sosialisasi di lingkungan kerja (occupational atau on-the-job socialization) antara lakilaki dan perempuan (Mason dan Mudrack 1996). Struktur penghargaan dan biaya-biaya yang terkait dengan peran pekerjaan akan mendorong laki-laki dan perempuan mempunyai persepsi etis yang tidak berbeda (Betz dkk. 1989).

Berbagai studi menunjukkan adanya perbedaan persepsi etis antara laki-laki dan perempuan pada berbagai area, misalnya bisnis dan akademik. Persepsi etis perempuan terhadap situasi etis bisnis (Rueger dan King 1992) dan akademik (Arlow 1991) relatif lebih tinggi dibanding pria. Berdasarkan usia, Peterson, Rhoads dan Vaught (2001) menemukan subyek perempuan pada kategori usia lebih muda memiliki kadar keyakinan etis (Ethical beliefs) yang lebih tinggi sementara pada kategori usia yang lebih tua pria-lah yang memiliki kadar keyakinan etis lebih tinggi. Selain itu perbedaan keyakinan etis antarjender menghilang pada kelompok usia yang lebih tua. Analisis meta yang dilakukan Borkowski dan Ugras (1998) menunjukkan dari 47 studi mengenai perbedaan persepsi etis antara laki-laki dan perempuan, 23 diantaranya menunjukkan hasil yang signifikan dan 16 menunjukkan hasil yang tidak signifikan.

Bukti empiris lainnya menunjukkan hasil yang sebaliknya dimana laki-laki dan perempuan mempunyai persepsi etis yang sama. Penelitian terhadap mahasiswa menunjukkan persepsi etis antara laki-laki dan perempuan tidak berbeda (Sikula dan Costa 1994, Stanga dan Turpen 1991, Tsalikis dan Ortiz-Buonafina 1990). Penelitian di Indonesia juga menunjukan tidak adaya 
perbedaan persepsi terhadap etika bisnis antara akuntan laki-laki, mahasiswa akuntansi, dan karyawan bagian akuntansi dengan akuntan perempuan, mahasiswi akuntansi, dan karyawati di bagian akuntansi (Martadi dan Suranta 2006). Mengacu pada teori gender socialization, dalam penelitian ini diharapkan terdapat perbedaan signifikan antara persepsi etis perempuan dengan laki-laki dalam memandang praktik manajemen laba.

\section{METODE PENELITIAN}

Sampel dalam penelitian ini terdiri dari praktisi akuntansi, dosen dan mahasiswa akuntansi. Pengambilan sampel dilakukan dengan metode covenience sampling dimana pemilihan sampel didasarkan pada kemudahan sehingga dapat dipilih sampel yang paling cepat dan mudah. Praktisi akuntansi terdiri dari para akuntan publik maupun manajer akuntansi yang diambil dari tiga kantor akuntan publik dan lima perusahaan di Jakarta dan Semarang. Sampel akademisi terdiri dari dosen dan mahasiwa akuntansi semester tujuh atau lebih. Mahasiswa semester akhir dipilih sebagai responden karena pada umumnya mahasiswa tersebut telah menempuh sebagian besar beban studinya sehingga diharapkan mampu memahami situasi yang digambarkan dalam kuisioner serta memberikan pendapatnya. Responden dosen dan mahasiswa akuntansi diambil dari dua perguruan tinggi di Jawa Tengah.

Data diperoleh dengan membagikan kuisioner kepada para responden baik melalui pos (dikirim ke contact person yang ada) atau langsung menemui responden. Kuisioner terdiri dari surat pengantar untuk meminta kesediaan responden mengisi kuisioner, kuisioner untuk mengetahui persepsi responden terhadap isu-isu yang berkaitan dengan etika yang dimodifikasi dari kuisioner yang disusun oleh Merchant dan Fischer dan Rosenzweig dalam Elias (2002). Kuisioner ini terdiri dari tujuh skenario manipulasi keputusan operasi dan tujuh skenario manipulasi akuntansi. Untuk mendapat gambaran persepsi yang lebih jelas dan mudah dimengerti oleh responden, modifikasi dilakukan dengan menambah satu skenario manipulasi operasi (nomor 7) dan mengubah skenario manipulasi akuntansi (nomor 14). Persepsi etis diukur berdasar skala Likert 1-5 dimana pada skor 1 responden menyatakan bahwa skenario yang diberikan adalah tindakan yang etis dan pada skor 5 reponden menyatakan sebaliknya. Kuisioner dapat dilihat pada Lampiran 1.

Dari 200 kuisioner yang didistribusikan, sebanyak 161 kuisioner yang dikembalikan (tingkat partisipasi sebesar $80,5 \%$ ) dan lima diantaranya tidak diisi dengan lengkap. Dengan demikian 
kuisioner yang dapat diolah lebih lanjut berjumlah 156 yang terdiri dari 65 kuisioner yang dikembalikan oleh praktisi dan 91 yang dikembalikan oleh akademisi.

Untuk mengetahui ada atau tidaknya perbedaan persepsi antara praktisi dan akademisi serta perbedaan persepsi atas manipulasi melalui keputusan operasi dan manipulasi akuntansi digunakan alat uji Mann-Whitney.

Sebelum uji Mann-Whitney, lebih dahulu dilakukan uji reliabilitas dan validitas. Pada studi ini reliabilitas instrumen ditunjukkan oleh Cronbach's alpha yang bernilai 0,77 (lebih besar dari 0,60) dan validitas diukur dengan teknik corrected item to total correlation. Skor komponen pertanyaan yang korelasinya dengan skor total bernilai kurang dari 0,60 tidak disertakan dalam pengujian selanjutnya.

\section{HASIL DAN PEMBAHASAN}

Tabel 1 menunjukkan skor rerata yang mencerminkan persepsi etis akademisi terhadap manajemen laba, manipulasi keputusan operasi, dan manipulasi akuntansi. Hasil uji MannWhitney menunjukkan bahwa terdapat perbedaan yang signifikan antara rerata skor persepsi etis akademisi dan praktisi, baik terhadap manajemen laba yang dilakukan melalui keputusan operasional maupun yang dilakukan melalui manipulasi akuntansi. Hal ini menunjukkan kecenderungan akademisi memandang manajemen laba lebih etis dibanding praktisi. Sebaliknya, akademisi cenderung menganggap manipulasi akuntansi lebih etis dibanding manipulasi keputusan operasi. Sebaliknya, praktisi cenderung menilai manipulasi keputusan operasi lebih etis dibanding manipulasi akuntansi. Hal ini searah dengan penelitian Cole dan Smith (1996) yang menemukan kesenjangan persepsi etis antara pelajar dengan pelaku bisnis.

Tabel 1. Skor Persepsi Etis Akademisi dan Praktisi Akuntansi terhadap Manajemen Laba*

\begin{tabular}{|l|c|c|c|c|}
\hline \multicolumn{1}{|c|}{ Tipe manipulasi } & $\begin{array}{c}\text { Rerata skor } \\
\text { akademisi }\end{array}$ & $\begin{array}{c}\text { Rerata skor } \\
\text { praktisi }\end{array}$ & p-value & $\mathrm{H}_{0}$ \\
\hline Manajemen laba & 2,5174 & 2,6532 & 0,000 & ditolak \\
\hline Manipulasi keputusan operasi & 2,5531 & 2,2808 & 0,046 & ditolak \\
\hline Manipulasi akuntansi & 2,4817 & 3,0256 & 0,000 & ditolak \\
\hline
\end{tabular}

* Nilai persepsi etis diukur pada skala 1-5. Semakin tinggi skor menunjuk pada penilaian yang semakin tidak etis atas kondisi yang diberikan.

Sumber: data diolah 
Pada pengujian lainnya, tidak ditemukan adanya perbedaan antara rerata skor persepsi etis akademisi terhadap manajemen laba yang dilakukan melalui keputusan operasi dan yang dilakukan melalui manipulasi akuntansi. Sebaliknya bagi praktisi, skor persepsi etis terhadap manajemen laba yang dilakukan melalui keputusan operasi dan yang dilakukan melalui manipulasi akuntansi berbeda secara nyata. Praktisi memandang manipulasi melalui keputusan operasi lebih etis dibanding manipulasi akuntansi. Hal ini senada dengan temuan Bruns dan Merchant (1990) dan Fischer dan Rosenzweig (1995). Bruns dan Merchant menyatakan bahwa hal ini dapat menyesatkan pengguna laporan keuangan atas informasi mengenai perusahaan dan mempengaruhi angka-angka dalam laporan akuntansi dari waktu ke waktu.

\section{Tabel 2. Skor Persepsi Etis terhadap Manipulasi Keputusan Operasi dan Manipulasi Akuntansi dari Akademisi dan Praktisi}

\begin{tabular}{|l|c|c|c|c|}
\hline \multicolumn{1}{|c|}{ Subyek } & $\begin{array}{c}\text { Rerata skor manipulasi } \\
\text { keputusan operasi }\end{array}$ & $\begin{array}{c}\text { Rerata skor manipulasi } \\
\text { akuntansi }\end{array}$ & p-value & $\mathrm{H}_{0}$ \\
\hline Akademisi & 2,5531 & 2,4817 & 0,487 & diterima \\
\hline Praktisi & 2,2808 & 3,0256 & 0,000 & ditolak \\
\hline
\end{tabular}

Sumber: data diolah

\section{Persepsi Etis Akademisi Akuntansi}

Tabel 2 menunjukkan akademisi dalam sampel penelitian ini cenderung lebih bisa menerima manajemen laba dari pada praktisi. Hasil penelitian ini sejalan dengan penelitian Ludigdo dan Machfoedz (1999) yang menemukan bahwa akuntan pendidik mempunyai persepsi etis terhadap etika bisnis yang lebih rendah dibanding akuntan publik. Cole dan Smith (1996) menyimpulkan hal tersebut terjadi karena cenderung rendahnya nilai-nilai etis di kalangan akademisi.

Kajian lebih lanjut menunjukkan besarnya rerata skor persepsi etis mahasiswa $(2,50)$ lebih rendah dibanding dosen $(2,77)$. Namun demikian, perbedaan persepsi etis tersebut tidak signifikan ( $p$ value 0,712). Di sisi lain, persepsi etis mahasiswa terhadap manipulasi akuntansi berbeda secara nyata dengan persepsi etis dosen ( $p$-value 0,021). Skor persepsi etis mahasiswa terhadap manipulasi akuntansi bernilai 1,50 dibanding skor dosen sebesar 2,26. Hal ini mengindikasikan 
subyek mahasiswa cenderung lebih bisa menerima manipulasi akuntansi dibanding dosen. Hal ini sejalan dengan hasil studi Fischer dan Rosenzweig (1995).

Hal-hal yang mungkin menjadi penyebab adalah bahwa mayoritas mahasiswa belum memahami masalah etika bisnis atau etika profesi, tidak berhasilnya pengajaran etika di perguruan tinggi, atau adanya pandangan dari kalangan akademisi yang menganggap bahwa praktik manajemen laba adalah sesuatu yang wajar dilakukan dalam bisnis.

Mengingat dosen merupakan fasilitator bagi mahasiswa dan mahasiswa adalah calon praktisi, rendahnya nilai-nilai etis di kalangan akademisi hendaknya mendapat perhatian yang lebih serius. Pemahaman mengenai pentingnya etika dalam bisnis dan profesi perlu ditingkatkan melalui forum-forum diskusi, seminar, maupun peningkatan efektifitas pengajaran etika. Di AS, Eynon, Hill dan Stevens (1997) menemukan bahwa mata kuliah etika memiliki pengaruh positif pada moral reasoning ability.

\section{Persepsi Etis Praktisi Akuntansi}

Dalam studinya terhadap 583 akuntan publik bersertifikasi/CPA, Elias (2004) menemukan bahwa akuntan publik yang bekerja pada organisasi yang memiliki standar etika tinggi memandang praktik manajemen laba lebih tidak etis dibanding yang bekerja pada organisasi dengan standar etika lebih rendah. Pada studi sejenis yang dilakukan oleh Martinson dan Ziegenfuss (2000), nilai etis organisasi tidak mempengaruhi persepsi etis anggotanya. Sementara Eynon, Hill dan Stevens (1997) menemukan bahwa akuntan di perusahaan kecil atau perusahaan pribadi memiliki moral reasoning ability yang lebih rendah dibanding yang bekerja di perusahaan besar (dan bahkan lebih rendah dari mahasiswa).

Hasil studi ini menunjukan responden praktisi akuntansi beranggapan bahwa melakukan manajemen laba melalui manipulasi keputusan operasi lebih dapat diterima dari pada melalui manipulasi akuntansi. Telaah lebih lanjut menunjukkan tidak terdapat perbedaan persepsi etis antara praktisi akuntansi yang bekerja di kantor akuntan publik dan praktisi akuntansi yang tidak bekerja di kantor akuntan publik ( $p$-value 0,174). Artinya, praktisi akuntansi dari KAP maupun non-KAP sama-sama menganggap bahwa praktik manajemen laba melalui manipulasi keputusan operasi sebagai tindakan yang lebih etis dibanding melalui manipulasi akuntansi.

Penerimaan praktisi akuntansi terhadap manipulasi keputusan operasi diduga merupakan pemahaman bahwa keputusan-keputusan operasi merupakan bagian dari fungsi/tugas 
manajer sehingga wajar jika manajer mengambil keputusan yang menguntungkan perusahaan atau pemegang saham. Sementara manajemen laba melalui manipulasi akuntansi dipandang merupakan rekayasa untuk keuntungan tertentu.

\section{Persepsi etis berdasarkan jender}

Tabel 3 menunjukkan bahwa pada sampel yang diteliti, tidak ditemukan adanya perbedaan persepsi etis yang nyata antara pelaku akuntansi perempuan dan laki-laki terhadap manajemen laba ( $p$-value 0,750 ) baik melalui manipulasi keputusan operasi ( $p$-value 0,637 ) maupun manipulasi akuntansi ( $p$-value 0,896).

Tabel 3. Skor Persepsi Etis terhadap Manajemen Laba berdasar Jender

\begin{tabular}{|l|c|c|c|c|}
\hline \multicolumn{1}{|c|}{ Tipe manipulasi } & $\begin{array}{c}\text { Rerata skor } \\
\text { perempuan } \\
(\mathrm{n}=85)\end{array}$ & $\begin{array}{c}\text { Rerata skor } \\
\text { laki-laki } \\
(\mathrm{n}=71)\end{array}$ & $\mathrm{p}$-value & $\mathrm{H}_{0}$ \\
\hline Manajemen laba & 2,5505 & 2,6021 & 0,750 & diterima \\
\hline Manipulasi keputusan operasi & 2,3951 & 2,4930 & 0,637 & diterima \\
\hline Manipulasi akuntansi & 2,7059 & 2,7113 & 0,896 & diterima \\
\hline
\end{tabular}

Sumber: data diolah

Telaah lebih lanjut menunjukkan bahwa baik pada kelompok mahasiswa (p-value 0,674) maupun profesional atau pelaku akuntansi yang sudah bekerja ( $p$-valve 0,320), tidak ditemukan adanya perbedaan yang nyata dalam persepsi etis terhadap manajemen laba berdasarkan jender. Dengan kata lain, perempuan dan laki-laki mempunyai pandangan yang sama terhadap praktik manajamen laba. Hal ini tidak sejalan dengan penelitian Rueger dan King (1992) namun mendukung penelitian Sikula dan Costa (1994), Tsalikis dan Ortiz-Buonafina (1990), dan Martadi dan Suranta (2006) untuk kasus di Indonesia. Hasil ini sejalan dengan teori occupational socialization yang menyatakan adanya kemiripan etika, norma, dan perilaku yang terkait dengan sosialisasi di lingkungan kerja (occupational atau on-the-job socialization) antara laki-laki dan perempuan (Mason dan Mudrack 1996). 


\section{SIMPULAN DAN SARAN}

Penelitian ini bertujuan untuk memperoleh gambaran mengenai persepsi etis para pelaku akuntansi (praktisi dan akademisi) terhadap praktik manajemen laba. Secara keseluruhan, akademisi memandang manajemen laba lebih etis dibanding praktisi. Hal ini perlu mendapat perhatian yang serius mengingat lingkungan akademik yang pada umumnya dianggap mempunyai nilai idealisme yang relatif lebih tinggi ternyata menunjukkan indikasi yang sebaliknya. Tinjauan yang lebih dalam untuk akademisi mengindikasikan subyek mahasiswa cenderung lebih bisa menerima manipulasi akuntansi dibanding dosen. Dengan demikian pemahaman etika bisnis dan profesi untuk mahasiswa perlu ditingkatkan melalui pengembangan kurikulum dengan memberi muatan etika pada mata kuliah-mata kuliah selain mata kuliah etika maupun forum-forum diskusi, seminar, maupun peningkatan efektivitas pengajaran.

Dalam studi ini, ditemukan adanya perbedaan nyata antara rerata skor persepsi etis praktisi terhadap manajemen laba yang dilakukan melalui keputusan operasi dan yang dilakukan melalui manipulasi akuntansi. Artinya, praktisi akuntansi lebih bisa menerima manajemen laba melalui manipulasi keputusan operasi dari pada melalui manipulasi akuntansi. Penerimaan praktisi akuntansi terhadap manipulasi keputusan operasi diduga merupakan pemahaman bahwa keputusan-keputusan operasional merupakan bagian dari fungsi/tugas manajer untuk memaksimalkan kesejahteraan pemegang saham.

Dari sisi jender, tidak ditemukan perbedaan yang nyata antara persepsi etis pelaku akuntansi perempuan dan laki-laki. Hasil yang sama juga ditemukan pada pembedaan jender pada kelompok mahasiswa dan kelompok yang sudah bekerja. Persamaan persepsi etis antara mahasiswa dan mahasiswi diduga disebabkan karena pendidikan etika dapat dipahami secara sama oleh seluruh mahasiswa sedangkan persamaan persepsi etis antara akuntan perempuan dan laki-laki yang sudah bekerja menunjukkan adanya adaptasi nilai-nilai dan keyakinan individu dengan lingkungan kerjanya.

Secara keseluruhan, rendahnya persepsi etis dikalangan akademisi khususnya mahasiswa dan adanya persamaan etis antara perempuan dan laki-laki pada seluruh kelompok subyek penelitian dapat dimungkinkan karena, di Indonesia, praktik-praktik manipulatif atau rekayasa dipandang sebagai sesuatu yang lumrah sehingga bagi masyarakat batasan-batasan antara etis dan tidak etis menjadi kabur. 


\section{KETERBATASAN PENELITIAN DAN SARAN UNTUK PENELITIAN MENDATANG}

Pada studi ini terdapat tiga responden akuntan akademisi yang juga merupakan akuntan praktisi. Pada saat pemilahan untuk menghitung rerata skor, ketiga jawaban dari respondenresponden tersebut disisihkan untuk menghindari bias. Penelitian mendatang disarankan untuk mengakomodasi kemungkinan adanya profesi rangkap. Terdapat kemungkinan akuntan pendidik yang juga menjadi praktisi memiliki persepsi yang cenderung mendekati persepsi akuntan praktisi atau level persepsinya berada diantara kedua kutub dikotomi. Sejauh ini sulit ditemukan studi yang berfokus pada persepsi etis dari akuntan yang memiliki profesi rangkap.

\section{DAFTAR PUSTAKA}

Arlow, P. 1991, 'Personal Characteristics in College Student: Evaluation of Business Ethics and Corporate Social responsibility, Journal of Business Ethics, Vol. 10, pp. 63-69

Betz, M., O'Connell, L. dan Shepard, J.M. 1989, 'Gender Differences in Proclivity for Unethical Behavior', Journal of Business Ethics, Vol. 8, pp. 321-324

Borkowski, S.C. dan Ugras, Y.J. 1998, 'Business Students and Ethics: A Meta-Analysis', Journal of Business Ethics, Vol. 17, pp. 1117-1127

Bruns, W. dan Merchant, K. 1990, 'The Dangerous Morality of Earnings Management', Management Accounting, Vol. 72, No. 2, pp. 22-25

Cole, B.C. dan Smith, D.L. 1996, 'Perceptions of Business Ethics: Students vs. Business People', Journal of Business Ethics, Vol. 15, No. 8, pp. 889-896

Elias, R.Z. 2002, 'Determinants of Earnings Management Ethics among Accountants', Journal of Business Ethics, Vol. 40, No. 1, pp. 33-45

2004, 'The Impact of Corporate Ethical Values on Perceptions of Earnings Management', Managerial Accounting Journal, Vol. 19, No. 1, pp. 84-98

Eynon, G., Hill, N.T. dan Stevens, K.T. 1997, 'Factors That Influence the Moral Reasoning Abilities of Accountants: Implications for Universties and Profession', Journal of Business Ethics, Vol. 16, No. 12/13, pp. 1297-1309

Fischer, M. dan Rosenzweig, K. 1995, 'Attitudes of Students and Accounting Practitioners Concerning the Ethical Acceptability of Earnings Management', Journal of Business Ethics Vol. 14, No. 6, pp 433-444

Ford, R.C. dan Richardson, W.D. 1994, 'Ethical Decision Making: A Review of the Empirical Literature', Journal of Business Ethics, Vol. 113, No. 3, pp. 205-221

Levitt, A. 1998, 'The Numbers Game', The CPA Journal, Vol. 68, December, pp. 14-19 
Ludigdo, U. dan Machfoedz, M. 1999, 'Persepsi Akuntan dan Mahasiswa terhadap Etika Bisnis', Jurnal Riset Akuntansi Indonesia, Vol. 2, No. 1, pp. 1-19

Martadi, I.F. dan Suranta, S 2006, 'Persepsi Akuntan, Mahasiswa Akuntansi, dan Karyawan Bagian Akuntansi Dipandang dari Segi Gender Terhadap Etika Bisnis dan Etika Profesi', Prosiding Simposium Akuntansi 9, K-AMEN 03, pp. 1-25

Martinson, O.B. dan Ziegenfuss, D.E. 2000, 'Looking at What Influences Ethical Perception and Judgment, Management Accounting Quarterly, Fall, pp. 41-47

Mason, E.S. dan Mudrack, P.E. 1996, 'Gender and Ethical Orientation: A Test of Gender and Occupational Socialization Theories', Journal of Business Ethics, Vol. 15, No. 6, pp. 599-604

Merchant, K.A. 1990, 'The Effects of Financial Controls on Data Manipulation and Management Myopia', Accounting, Organizations dan Society, Vol. 15, No. 4, pp. 297-313

Parfet, W.U. 2001, 'Accounting Subjectivity and Earnings Management: A Preparer Perspective', Accounting Horizons, Vol. 14, No. 4, pp. 481-488

Peterson, D., Rhoads, A., dan Vaught, B.C. 2001, 'Ethical Beliefs of Business Professionals: A Study of Gender, Age, and External Factors', Journal of Business Ethics, Vol. 31, No. 3, pp. 225-232

Pomeranz, F. 2004, 'Ethics: Towards Globalization', Managerial Auditing Journal, Vol. 19, No. 1, pp. 8-14

Rahmawati, S. dan Sulardi 2003, 'Persepsi Etis Akuntan Pendidik, Mahasiswa Akuntansi dan Manajer terhadap Praktik Earnings Management (Survei di Wilayah Surakarta)', Jurnal Akuntansi dan Bisnis, Vol. 3, No. 2, pp. 146-159

Rueger, D. dan King, E.W. 1992, 'A Study of the Effect of Age and Gender upon Student Business Ethics', Journal of Business Ethics, Vol. 11, No. 3, pp. 179-186

Rustiana 2006, 'Persepsi Etika Mahasiswa Akuntansi dan Auditor dalam Situasi Dilema Etis Akuntansi', Jurnal Bisnis dan Ekonomi Kinerja, Vol. 10, No. 2, pp. 116 -128

Sikula, A. dan Costa, A 1994, 'Are Women More Ethical than Men?', Journal of Business Ethics, Vol. 13, pp. 859- 871

Spain, J.W., Brewer, P., Brewer, V. dan Garner, S.J. 2002, 'Ethics and Geography - Impact of Geographical Cultural Differences on Students Ethical Decision', Journal of Business Ethics, Vol. 41, pp. 187-194

Stanga, K.G. dan Turpen, R.A. 1991, 'Ethical Judgments on Selected Accounting Issues: An Empirical Study', Journal of Business Ethics, Vol. 10, pp. 739-747

Tsalikis, J. dan Ortiz-Buonafina, M 1990, 'Ethical Beliefs' Differences of Males and Females', Journal of Business Ethics, Vol. 9, 509- 517 
Zoraifi, R. 2005, 'Pengaruh Locus of Control, Tingkat Pendidikan, Pengalaman Kerja, dan Pertimbangan Etis terhadap Perilaku Auditor dalam Situasi Konflik Audit', Jurnal Akuntansi dan Bisnis, Vol. 5, No. 1, pp. 12-26 


\section{Bibliografi penulis}

\section{Komala Inggarwati}

Staf pengajar di Fakultas Ekonomika dan Bisnis Universitas Kristen Satya Wacana (FEB UKSW) sejak tahun 2001. Menyelesaikan studi S1 Manajemen di FEB UKSW tahun 1989 dan studi S2 Magister Manajemen di Universitas Indonesia tahun 1993. Saat ini mengajar matakuliah Akuntansi Manajerial, Kewirausahaan, dan Simulasi bisnis. Terlibat aktif dalam tim pengembangan kewirausahaan mahasiswa di FEB UKSW dan menjadi nara sumber berbagai pelatihan kewirausahaan mahasiswa. Mempunyai minat penelitian pada bidang perilaku kewirausahaan, bisnis keluarga, dan etika.

Email address : komala@staff.uksw.edu

\section{Arnold Kaudin}

Staf pengajar di Fakultas Ekonomika dan Bisnis Universitas Kristen Satya Wacana sejak tahun 2004. Menyelesaikan studi S1 Manajemen di Fakultas Ekonomi Universitas Padjadjaran tahun 1998, studi S2 Magister Manajemen di Universitas Gadjah Mada tahun 2004 dan Master of Commerce (In finance) di The University of Sydney tahun 2009. Area penelitian yang diminati adalah behavioral finance, behavioral entrepreneurship, dan etika.

Email address: arnold.kaudin@staff.uksw.edu 